\title{
Non-destructive evaluation of residual compressive strength of post-heated reinforced concrete columns
}

DOI:

10.1016/j.conbuildmat.2016.05.022

\section{Document Version}

Accepted author manuscript

Link to publication record in Manchester Research Explorer

\section{Citation for published version (APA):}

Yaqub, M., \& Bailey, C. (2016). Non-destructive evaluation of residual compressive strength of post-heated reinforced concrete columns. Construction and Building Materials, 120, 482-493.

https://doi.org/10.1016/j.conbuildmat.2016.05.022

\section{Published in:}

Construction and Building Materials

\section{Citing this paper}

Please note that where the full-text provided on Manchester Research Explorer is the Author Accepted Manuscript or Proof version this may differ from the final Published version. If citing, it is advised that you check and use the publisher's definitive version.

\section{General rights}

Copyright and moral rights for the publications made accessible in the Research Explorer are retained by the authors and/or other copyright owners and it is a condition of accessing publications that users recognise and abide by the legal requirements associated with these rights.

\section{Takedown policy}

If you believe that this document breaches copyright please refer to the University of Manchester's Takedown Procedures [http://man.ac.uk/04Y6Bo] or contact uml.scholarlycommunications@manchester.ac.uk providing relevant details, so we can investigate your claim.

\section{OPEN ACCESS}




\title{
Non-destructive evaluation of residual compressive strength of post-heated reinforced concrete columns
}

\author{
M. Yaqub, ${ }^{\mathrm{a}, * \text { C.G. Bailey }}{ }^{\mathrm{b}}$ \\ a University of Engineering \& Technology Taxila, Pakistan \\ ${ }^{\mathrm{b}}$ The University of Manchester, UK
}

\section{A R T I C L E I N F O}

\section{Article history:}

Received 6 October 2012

Received in revised form 1 May 2016

Accepted 5 May 2016

Available online xxx

\section{Keywords:}

Columns

Concrete

Residual compressive strength

Temperature

Ultrasonic tests

\begin{abstract}
A B S T R A C T
An experimental study was carried out to evaluate the residual compressive strength of post-heated reinforced concrete columns using techniques applicable in the field. A total of thirty-five reinforced concrete columns (along with three standard cubes for each column) were tested. Ultrasonic pulse velocity tests were carried out on un-damaged and heat damaged reinforced concrete columns and on the related un-damaged and heat damaged concrete cubes. The reinforced concrete columns (fourteen square and thirteen circular) along with three cubes for each column were heated to a uniform temperature of $500{ }^{\circ} \mathrm{C}$ at a rate of $150{ }^{\circ} \mathrm{C} / \mathrm{h}$. In addition, fifteen undamaged and fifteen heat damaged extra cubes cast from the same batches of concrete (used for casting the columns) were also tested in order to develop a relationship between pulse velocity tests and the residual compressive strength when the cubes were heated over a temperature range. The fifteen heat-damaged cubes were heated with the same heating rate as that used for the columns to uniform temperatures of $200{ }^{\circ} \mathrm{C}, 300{ }^{\circ} \mathrm{C}, 450{ }^{\circ} \mathrm{C}, 500{ }^{\circ} \mathrm{C}$ or $550{ }^{\circ} \mathrm{C}$. It was shown that the residual compressive strength of concrete on the 7th day of cooling at ambient temperature after exposing to $200{ }^{\circ} \mathrm{C}, 300{ }^{\circ} \mathrm{C}, 450{ }^{\circ} \mathrm{C}, 500{ }^{\circ} \mathrm{C}$ and $550{ }^{\circ} \mathrm{C}$ was found to be $80 \%, 76 \%, 60 \%, 47 \%$ and $30 \%$ of the original un-heated strength respectively. A general relationship was developed between the ultrasonic pulse velocity and the residual compressive strength of cubes over a temperature range of $20{ }^{\circ} \mathrm{C}-550{ }^{\circ} \mathrm{C}$ in order to relate the compressive strength of cubes directly to the in-situ compressive strength of concrete in the reinforced concrete post-heated columns. Additionally, the theoretical and experimental tested values of the axial compressive strength of un-damaged and heat damaged columns were compared in order to evaluate the residual compressive strength of columns. It was found that the theoretical and tested values agreed well for un-damaged $\left(20^{\circ} \mathrm{C}\right)$ and heat damaged $\left(500^{\circ} \mathrm{C}\right)$ square and circular columns.
\end{abstract}

CC 2016 Published by Elsevier Ltd.

\section{Introduction}

Concrete buildings generally perform well in a fire due to the concrete's low thermal diffusivity which slows the increase in temperatures, and thus the decrease in strength and stiffness of the structure during a fire. The continuity between structural members within a reinforced concrete building also aids the survival of the building as load is distributed away from heated weak areas towards the unheated stronger areas.

Following a fire, within a concrete building, knowledge of the residual strength of the concrete members is required to allow an assessment to be conducted to decide if the building should either be demolished or reinstated. The residual strength of dense concrete after cooling varies depending on maximum temperature attained, mix proportions and conditions of loading during heating [1]. For temperatures up to $100{ }^{\circ} \mathrm{C}$, there will be no loss of strength even with prolonged exposure to this temperature [2] and also once the concrete cools down there will be no further reduction in strength. The decrease in strength will start above $200{ }^{\circ} \mathrm{C}$, although up to approximately $300{ }^{\circ} \mathrm{C}$ the residual strength of structural concrete is not severely reduced [3]. Over $300{ }^{\circ} \mathrm{C}$ the residual strength is significantly

\footnotetext{
* Corresponding author.

Email address: yaqub_structure@yahoo.com (M. Yaqub)
}

reduced. At $500{ }^{\circ} \mathrm{C}$ concrete losses about $50 \%$ of its original strength, and at $600{ }^{\circ} \mathrm{C}$, the reduction is about $75 \%[4,5]$. The Concrete Society Report [6] considered zero strength after $300{ }^{\circ} \mathrm{C}$ for a conservative assumption of buildings following a fire.

To determine the average damage in concrete structures, the structural members can be divided into inner, intermediate, and outer zones according to the temperature distribution, as shown in Fig. 1. According to the Concrete Society TR 33 [4], CIB W14 Report [7] and fib bulletin 46 [8], for the inner zone where the temperature did not exceed $100{ }^{\circ} \mathrm{C}$, the damage factor is 1 . For the intermediate zone where the maximum temperature is between $200{ }^{\circ} \mathrm{C}$ and $300{ }^{\circ} \mathrm{C}$, the damage factor is 0.85 . For the outer zone where maximum temperature reached between $300{ }^{\circ} \mathrm{C}$ and $500{ }^{\circ} \mathrm{C}$, the damage factor is 0.4 . However, the damage factor should be considered zero in the outer zone where temperatures exceeded $500{ }^{\circ} \mathrm{C}$.

The effect of high temperature on the residual yield strength of typical reinforcing steel bars after cooling is shown in Fig. 2. The original yield stress after cooling is almost completely recovered from temperatures up to $450{ }^{\circ} \mathrm{C}$ for cold worked steel and $600{ }^{\circ} \mathrm{C}$ for hot rolled steel. However, above these temperatures, there will be a loss in yield strength after cooling [4]. On cooling from $800{ }^{\circ} \mathrm{C}$, the yield stress is reduced by $30 \%$ for cold worked bars and $5 \%$ for hot rolled bars [9].The actual loss in strength depends on the heating conditions and type of steel. However, the conservative values given in 


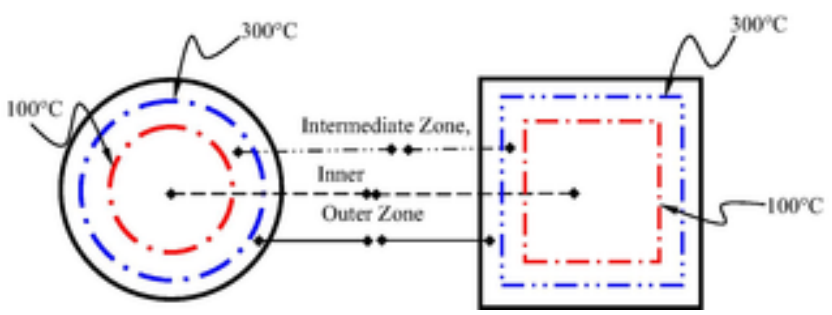

Fig. 1. Fire Damage zoning for the circular and square columns [4].

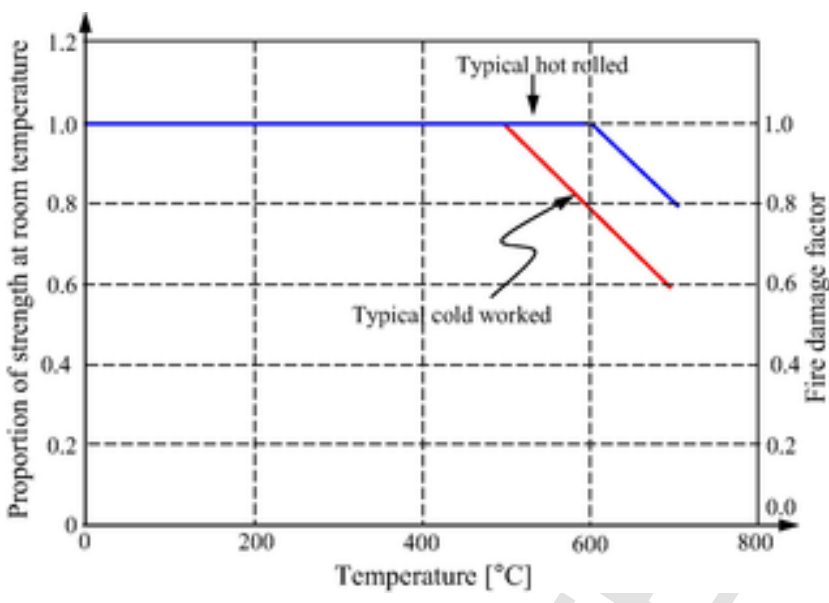

Fig. 2. Yield Strength of reinforcing steels at room temperature after heating to an elevated temperature [4].

Fig. 2, for temperatures up to $700{ }^{\circ} \mathrm{C}$, would be sufficient for most purposes [4].

There are many factors which contributed in the reduction of concrete strength during the fire. However the primary effect of fire on concrete structures depends on the peak internal temperature reached within the cross section of the structural members during the fire. The peak internal temperature within the cross-section of the structural members is related to the severity of fire and the duration of fire. In a real fire situation, the severity of fire is not uniform throughout the building and may have remained limited to a small area for a long time or extensive spread may have occurred. The rate of temperature rise may have been faster, or slower, than in the standard fire test. Different parts of the building may have reached different peaks of temperatures due to different fire intensities. There are many approaches in the literature to judge the maximum fire duration and the maximum temperatures reached within the buildings during the fire. Unfortunately, all the available approaches in the literature give only the clue about maximum particular temperatures but they do not give the direct indication regarding the actual surface temperatures of the structural members and the total duration of exposure to that temperature. Generally speaking, practically none of the approachesavailable in the literature gives complete reliable results.

The assessment of the residual capacity of fire damaged reinforced concrete structures requires an appropriate account of the temperature reached within the cross-section of the structural members. There are three approaches to predict the distribution of temperature within the cross-section of structural members. Firstly, the use the charts for temperature distributions within concrete elements based on the standard fire tests given in BS EN1992 Part 1-2 [10]. Secondly to use simple formulae proposed by Wickstrom [11]. Thirdly, which is considered a more realistic approach, is to estimate the temperature distribution within the cross-section using finite element methods for heat transfer analysis. Since, the temperature distribution within the cross-section of the structural member is directly related to the actual surface temperature of the structural member and the total duration of exposure to that temperature. Therefore, even having the availability of the approaches to predict the exact distribution of temperature within the cross-section of the structural members, it is also not possible to find the reliable actual temperature distribution within the cross section of the structural members during the real fire.

For the evaluation of the residual strength of fire damaged concrete there are a number of in-situ and laboratory-based techniques available to diagnose the concrete's condition [7]. The in-situ testing techniques include visual inspection, non-destructive testing, and taking samples of concrete and reinforcement for testing in the laboratory. The in-situ non-destructive tests include hammer soundings, rebound hammer (Schmidt hammer) and the PUNDIT (Portable Ultrasonic Non-Destructive Digital Indicating Tester). The rebound hammer test needs a flat concrete surface and a large number of tests are required to reduce the effects of variability. Therefore, it is not generally suitable for use on spalled surfaces, which can occur with fire damaged concrete [7]. The most direct and reliable strength assessment test involves extracting cores from the fire damaged concrete areas. However, extracting cores from existing reinforced concrete columns can be risky due to the possibility of cutting the main reinforcing bars during extraction. Therefore, the extraction of cores directly from columns should generally be avoided, unless the exact position of the reinforcement is known.

The ultrasonic pulse velocity test is a well-established and simple tool for practicing engineers to evaluate the in-situ residual compressive strength of reinforced concrete structures. The test is very sensitive since small changes in the pulse velocity usually reflect relatively large changes in the condition of the concrete. For this reason, it is very important to obtain the highest possible accuracy of both the 
transit time and path length measurements since the pulse velocity depends on both. Providing a direct transmission arrangement for the transducers will give maximum sensitivity and provide a well-defined path length. Therefore, the best method is to place the transmitting transducer on the opposite face to the receiving transducer on the surface of the structural member, which is generally easier to achieve on columns compared to other structural members such as slabs.

Currently there is no fundamental relationship between the pulse velocity and the residual compressive strength of post-heated concrete. Therefore, it is necessary to obtain a direct relationship between the residual compressive strength of fire damaged concrete and the ultrasonic pulse velocity to obtain reliable results for the in-situ residual compressive strength. In this research work, a general relationship between the ultrasonic pulse velocity and the residual compressive strength of heat damaged concrete cubes is investigated in order to relate directly the cube compressive strength to the in-situ residual compressive strength of concrete in fire damaged reinforced concrete columns.

The relationship between the pulse velocity and compressive strength proposed by various investigators [12-15] can vary between concrete mixes, due to the different type of aggregates, aggregate-cement ratio, water-cement ratios, age of concrete, size and grading of aggregate, curing conditions, air content, moisture content and density. It was found that due to the dehydration of concrete by driving out of moisture content at elevated temperature and micro cracking, there was notable difference in pulse velocities for a given compressive strength of fire damaged and undamaged concrete [16]. It was also observed that the reinforcing bars running transverse to the pulse velocity measuring path had no significant effect upon measured pulse velocities values. However, the pulse velocities measured values were affected considerably by the presence of reinforcing bars running along the pulse velocity measuring path [12].

The post heating testing involved in the present study is based on the uniform heating of concrete which does not represent a real fire scenario, but does provide the foundation for the development of an approach that can finally be used in the field conservatively. In a real fire, the higher external temperatures (greater than $900{ }^{\circ} \mathrm{C}$ ) are likely to be encountered during fire within the buildings $[4,8]$. However, the external temperatures and the temperatures within the cross-section of the structural member both are very important because they are contributing in developing the thermal gradient. The temperature distribution during the fire exposure is not uniform throughout the cross-section of the column, causing non-uniform reduction in the strength of the concrete and reinforcing steel. The assessment of the residual compressive strength of fire-damaged concrete columns to decide whether a column is still structurally sound depends largely on the accuracy of determining the maximum temperature distribution within the crosssection of the fire damaged column. In this study, the internal temperatures ranging from $200{ }^{\circ} \mathrm{C}$ to $550{ }^{\circ} \mathrm{C}$ within the cross section are considered for the fire damaged repairable concrete.

Consequently, it is very difficult and complicated to evaluate the in-situ residual compressive strength of actual fire damaged reinforced concrete columns since only the temperature of the outside layer is drastically increased, and the temperature of the internal concrete generally remains comparatively low depending upon the intensity of fire, duration of fire and the rate of heat transfer in the concrete [17]. In this paper the first steps to develop a simple method is proposed to calculate the in-situ residual compressive strength of concrete and load carrying capacity of the existing post-heated columns without estimating the actual peak external temperature, the total duration of fire exposure to that temperature and the actual tem- perature distribution within the cross-section of columns during the fire.

The work presented in this paper is currently based on uniformly heated columns and will need to be extended to non-uniformly heated columns in the future. The final objective of this research is to provide an easy, safe (conservative) and professional design approach for estimating the in-situ residual compressive strength of existing fire damaged reinforced concrete columns using the developed relationship between the ultrasonic pulse velocity and the residual compressive strength to avoid directly the extraction of concrete cores from existing reinforced concrete post-heated columns. However, in this study, the developed relationship between the pulse velocity and the residual strength of concrete is extended to evaluate the residual strength of existing fire damaged concrete columns in the range of $200{ }^{\circ} \mathrm{C}-550{ }^{\circ} \mathrm{C}$ for siliceous aggregate concrete.

\section{Experimental work}

\subsection{Test specimens}

In order to relate the residual compressive strength and the ultrasonic pulse velocity of un-heated and post-heated cubes with the insitu strength of existing un-heated and post-heated columns, thirtyfive reinforced concrete columns (eighteen square and seventeen circular) were cast with siliceous (gravel) aggregate concrete along with concrete cubes in the Structural Engineering Laboratory, at the University of Manchester, UK. The reinforced concrete columns and strength controlling cubes were cast from the same concrete mix and cured under identical conditions in the laboratory environment. All the columns were $1000 \mathrm{~mm}$ in length. The square columns had a $200 \times 200 \mathrm{~mm}$ cross-section while the circular columns had a $200 \mathrm{~mm}$ diameter. The square columns were reinforced with eight $10 \mathrm{~mm}$ diameter longitudinal reinforcing deformed bars while the circular columns were reinforced with six $10 \mathrm{~mm}$ diameter longitudinal reinforcing deformed bars. The longitudinal reinforcement ratio used in the square and circular columns was $1.6 \%$ and $1.5 \%$ respectively. In all columns, $6 \mathrm{~mm}$ diameter deformed bars were used as link bars spaced at $100 \mathrm{~mm}$ centres. The yield strength of the main reinforcing bars and link bars was $553 \mathrm{MPa}$ and $570 \mathrm{MPa}$ respectively. For the square columns $25 \mathrm{~mm}$ concrete cover, and for the circular columns $30 \mathrm{~mm}$ concrete cover, was provided to the longitudinal reinforcement. The arrangement of the reinforcement in the square and circular reinforced concrete columns is shown in Fig. 3.

\subsection{Casting of specimens}

All square columns were cast in the horizontal position while all the circular columns were cast in the vertical position. The materials used in the concrete mix were sand, siliceous (gravel) aggregate and Ordinary Portland Cement. The mix ratio and the maximum water cement ratio $(\mathrm{w} / \mathrm{c})$ used in the concrete mix design was $1: 1.75: 3.5$ and 0.55 respectively. The maximum size of aggregate used in the mix design was $10 \mathrm{~mm}$. The compaction in the square columns was carried out using a vibrating table while in the circular columns the compaction was carried out using an internal poker vibrator. For each column, three cubes of $100 \mathrm{~mm}$ size were cast from the same batch of concrete to monitor the strength of columns. The average of axial compressive strength of three strength controlling cubes for each square and circular column at the time of testing before and after heating is shown in Tables 1 and 2. To monitor the temperature in the columns, two K-type thermocouples were embedded in each column, 

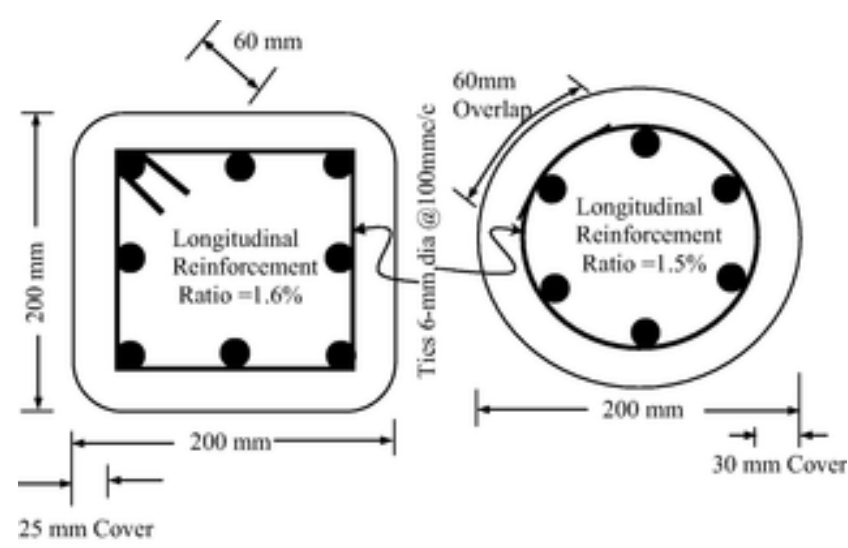

Fig. 3. Reinforcement arrangement in the square and circular columns.

one in the centre at mid-height and the other was attached to the longitudinal reinforcement during casting of the columns.

Thirty $150 \times 150 \times 150 \mathrm{~mm}$ and twelve $100 \times 100 \times 100 \mathrm{~mm}$ size additional cubes were also made from the same batches of concrete mix, which were used for casting the columns, in order to consider the size effect on the retained compressive strength of the columns. For the cubes heated in the furnace, one K-type thermocouple was embedded in the centre at mid-height to record the temperature at the time of heating. The curing of all specimens was carried out with canvas that was kept continuously wet with water. In order to retain the water content, a polythene sheet was used to cover the surface of all the specimens. All the specimens were kept for curing up to fourteen days and then left in the laboratory environment until the day of testing. All cubes were also kept with the columns for curing until the day of testing.

\section{Test condition and procedure}

\subsection{Heating of cubes}

Fifteen $150 \times 150 \times 150 \mathrm{~mm}$ and nine $100 \times 100 \times 100 \mathrm{~mm}$ size cubes were heated at a rate of $150{ }^{\circ} \mathrm{C} / \mathrm{h}$ in an electric furnace of size $1.6 \times 1.2 \times 1.5 \mathrm{~m}$. The cubes were heated at an age of more than nine months after casting. Three cubes of $150 \times 150 \times 150 \mathrm{~mm}$ size were heated at the same time in an electric furnace for the temperatures of $200{ }^{\circ} \mathrm{C}, 300{ }^{\circ} \mathrm{C}, 450{ }^{\circ} \mathrm{C}, 500{ }^{\circ} \mathrm{C}$ and $550{ }^{\circ} \mathrm{C}$ in order to estimate the retained concrete compressive strength. At $450{ }^{\circ} \mathrm{C}, 500^{\circ} \mathrm{C}$ and $550{ }^{\circ} \mathrm{C}$ temperatures, nine cubes of size $100 \times 100 \times 100 \mathrm{~mm}$, three for each temperature were also tested along with the $150 \times 150 \times 150 \mathrm{~mm}$ cubes to consider the effect of specimen size on the retained compressive strength. An un-stressed residual strength test was carried out to evaluate the residual compressive strength of the cubes, which is considered to be more conservative in terms of design for assessing the post-fire or residual properties of concrete after fire [3,18-20].

One K-type thermocouple was embedded at mid-height in the centre of each cube in order to monitor the temperature. The temperatures within the furnace were controlled by using two type K-thermocouples, one installed at mid-height and other at the top. When the average furnace temperatures reached the specified temperatures of $200{ }^{\circ} \mathrm{C}, 300{ }^{\circ} \mathrm{C}, 450{ }^{\circ} \mathrm{C}, 500{ }^{\circ} \mathrm{C}$ or $550{ }^{\circ} \mathrm{C}$, the furnace temperatures were kept constant until the temperatures at the centre of the cubes reached the specified temperatures. After achieving complete uniformity of temperature inside the furnace and throughout the cubes, the furnace was switched off and the cubes were allowed to cool down naturally inside the furnace. Once cooled, the specimens were taken out of the furnace and stored in a dry condition at room temperature for 7 days until testing. Fig. 4 shows the time-temperature curves for cubes heated to $200{ }^{\circ} \mathrm{C}, 300{ }^{\circ} \mathrm{C}, 450{ }^{\circ} \mathrm{C}, 500{ }^{\circ} \mathrm{C}$ and $550{ }^{\circ} \mathrm{C}$ respectively.

\subsection{Heating of columns}

For the heated columns, fourteen square and thirteen circular reinforced concrete columns were heated in an electric furnace of size $1.6 \times 1.2 \times 1.5 \mathrm{~m}$. All columns were heated at an age of more than nine months after casting in order to reduce the moisture content. A maximum of six columns were heated at the same time along with nine cubes of size $100 \times 100 \times 100 \mathrm{~mm}$. The average heating rate used throughout the experiment was $150{ }^{\circ} \mathrm{C} / \mathrm{h}$. The temperatures of the concrete columns were monitored at the centre of the cross-section, and at one of the longitudinal reinforcement positions, at mid-height.

When the average furnace temperature reached $500{ }^{\circ} \mathrm{C}$, the furnace temperature was kept constant until the temperature at the centre of the columns reached the same specified temperature $\left(500{ }^{\circ} \mathrm{C}\right)$. When the temperature at the centre of the concrete columns coincided with the furnace temperature then the furnace was switched off and the specimens were allowed to cool down naturally in the furnace. After cooling down, the specimens were removed from the furnace and kept in a dry condition at room temperature in the laboratory environment until the day of testing. The columns were heated to a uniform temperature of $500{ }^{\circ} \mathrm{C}$ since at this temperature concrete retains a residual compressive strength of approximately $50 \%$ of its original strength for normal strength gravel aggregate concrete [21]. The time-temperature curves for the square and circular columns is also shown in Fig. 4.

\subsection{Moisture content}

The weight of the cubes for the square and circular columns was measured before and after heating. The moisture content was calculated by subtracting the weight of post-heated cubes from the measured weight of the un-heated cubes and dividing by the weight of post-heated cubes.

\subsection{Ultrasonic testing}

The PUNDIT (Portable Ultrasonic Non-Destructive Digital Indicating Tester) with a direct transmission mode was used to measure 
Table 1

Ultimate compressive strength of cubes associated for square columns (tested at the same time as the columns).

\begin{tabular}{|c|c|c|c|c|c|c|}
\hline Compressive Stre & ength of Tes & t Cubes $\mathrm{C}$ & ast with $\mathrm{Sc}$ & quare Colu & ans & $\begin{array}{l}\text { Moisture } \\
\text { Content } \\
(\%)\end{array}$ \\
\hline \multirow[t]{2}{*}{$\begin{array}{l}\text { Testing } \\
\text { Conditions }\end{array}$} & \multirow[t]{2}{*}{ Specimen } & \multicolumn{2}{|c|}{$\begin{array}{l}\text { Testing period } \\
\text { (Months) }\end{array}$} & \multicolumn{2}{|c|}{$\begin{array}{l}\text { Ultimate } \\
\text { Compressive } \\
\text { Strength } \mathrm{MPa} \\
\text { (100 mm Cubes) }\end{array}$} & \\
\hline & & $\begin{array}{l}\text { After } \\
\text { casting }\end{array}$ & $\begin{array}{l}\text { After } \\
\text { heating }\end{array}$ & $\begin{array}{l}\text { Un- } \\
\text { heated }\end{array}$ & $\begin{array}{l}\text { Post- } \\
\text { heated }\end{array}$ & \\
\hline $\begin{array}{l}\text { Un-heated } \\
\left(20^{\circ} \mathrm{C}\right)\end{array}$ & $\mathrm{S} 1$ & 13 & - & 58 & - & - \\
\hline $\begin{array}{l}\text { Un-heated } \\
\left(20^{\circ} \mathrm{C}\right)\end{array}$ & $\mathrm{S} 2$ & 13 & - & 56 & - & - \\
\hline $\begin{array}{l}\text { Post-heated } \\
\left(500{ }^{\circ} \mathrm{C}\right)\end{array}$ & $\mathrm{S} 3$ & 10 & 2 & 53 & 22 & 3.6 \\
\hline $\begin{array}{l}\text { Post- } \\
\text { heated }\left(500{ }^{\circ} \mathrm{C}\right)\end{array}$ & $\mathrm{S} 4$ & 10 & 2 & 53 & 22 & 3.6 \\
\hline $\begin{array}{l}\text { Post-heated } \\
\left(500^{\circ} \mathrm{C}\right)\end{array}$ & S5 & 14 & 2 & 50 & 20 & 3.8 \\
\hline $\begin{array}{l}\text { Post-heated } \\
\left(500^{\circ} \mathrm{C}\right)\end{array}$ & S6 & 14 & 2 & 52 & 23 & 3.8 \\
\hline $\begin{array}{l}\text { Post-heated } \\
\left(500{ }^{\circ} \mathrm{C}\right)\end{array}$ & S7 & 12 & 2 & 53 & 22 & 3.4 \\
\hline $\begin{array}{l}\text { Post-heated } \\
\left(500^{\circ} \mathrm{C}\right)\end{array}$ & S8 & 19 & 2 & 55 & 24 & 3.5 \\
\hline $\begin{array}{l}\text { Post-heated } \\
\left(500^{\circ} \mathrm{C}\right)\end{array}$ & S9 & 19 & 2 & 52 & 21 & 3.5 \\
\hline $\begin{array}{l}\text { Post-heated } \\
\left(500^{\circ} \mathrm{C}\right)\end{array}$ & $\mathrm{S} 10$ & 19 & 2 & 52 & 22 & 3.4 \\
\hline $\begin{array}{l}\text { Un-heated } \\
\left(20^{\circ} \mathrm{C}\right)\end{array}$ & S11 & 16 & - & 56 & - & - \\
\hline $\begin{array}{l}\text { Un-heated } \\
\left(20^{\circ} \mathrm{C}\right)\end{array}$ & $\mathrm{S} 12$ & 16 & - & 58 & - & - \\
\hline $\begin{array}{l}\text { Post-heated } \\
\left(500^{\circ} \mathrm{C}\right)\end{array}$ & S13 & 11 & 2 & 53 & 24 & 3.5 \\
\hline $\begin{array}{l}\text { Post-heated } \\
\left(500^{\circ} \mathrm{C}\right)\end{array}$ & $\mathrm{S} 14$ & 11 & 2 & 54 & 25 & 3.5 \\
\hline $\begin{array}{l}\text { Post-heated } \\
\left(500^{\circ} \mathrm{C}\right)\end{array}$ & $\mathrm{S} 15$ & 15 & 2 & 54 & 24 & 3.8 \\
\hline $\begin{array}{l}\text { Post-heated } \\
\left(500^{\circ} \mathrm{C}\right)\end{array}$ & $\mathrm{S} 16$ & 16 & 3 & 51 & 26 & 3.8 \\
\hline $\begin{array}{l}\text { Post-heated } \\
\left(500^{\circ} \mathrm{C}\right)\end{array}$ & S17 & 12 & 3 & 53 & 21 & 3.7 \\
\hline $\begin{array}{l}\text { Post-heated } \\
\left(500^{\circ} \mathrm{C}\right)\end{array}$ & $\mathrm{S} 18$ & 12 & 3 & 53 & 22 & 3.7 \\
\hline Average Compre & ssive Streng & & & 54 & 23 & 3.6 \\
\hline Standard Deviatic & & & & \pm 2.2 & \pm 1.7 & \pm 0.15 \\
\hline Average Compre & ssive Streng & th Percen & age Loss & $57.00 \%$ & & \\
\hline
\end{tabular}

the ultrasonic pulse velocity of the concrete, adopting the procedure given in BS EN 12504-4:2004 [14]. After more than nine months from when the concrete cubes and columns were cast from the same mix, and cured under identical conditions, pulse velocity measurements were made with the PUNDIT in the un-heated and post-heated cubes and columns. Petroleum Jelly was used to make smooth surfaces both on the concrete cubes and columns. The transmitting and receiving transducers ( $54 \mathrm{kHz}$ frequency) were placed on the opposite faces of the concrete cubes and columns. The distance between the transducers was divided by the transit time to obtain the pulse velocity through the concrete. Three readings were taken at the middle for each cube.

For the reinforced concrete columns, the ultrasonic pulse velocity was measured at two positions, the top $(75 \mathrm{~mm}$ below the top edge of column) and middle, and three readings were taken at each position. To avoid the reinforcement, the positions of the transducers were se-
Table 2

Ultimate compressive strength of cubes associated for circular columns (tested at the same time as the columns).

\begin{tabular}{|c|c|c|c|c|c|c|}
\hline \multicolumn{6}{|c|}{ Compressive Strength of Test Cubes Cast with Circular Columns } & $\begin{array}{l}\text { Moisture } \\
\text { Content } \\
(\%)\end{array}$ \\
\hline \multirow[t]{2}{*}{$\begin{array}{l}\text { Testing } \\
\text { Conditions }\end{array}$} & \multirow[t]{2}{*}{ Specimen } & \multicolumn{2}{|c|}{$\begin{array}{l}\text { Testing Period } \\
\text { (Months) }\end{array}$} & \multicolumn{2}{|c|}{$\begin{array}{l}\text { Ultimate Compress } \\
\text { Strength } \mathrm{MPa} \\
\text { (100 mm cubes })\end{array}$} & \multirow[t]{2}{*}{ 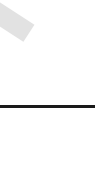 } \\
\hline & & $\begin{array}{l}\text { After } \\
\text { casting }\end{array}$ & $\begin{array}{l}\text { After } \\
\text { heating }\end{array}$ & $\begin{array}{l}\text { Un- } \\
\text { heated }\end{array}$ & $\begin{array}{l}\text { Post- } \\
\text { heated }\end{array}$ & \\
\hline $\begin{array}{l}\text { Un-heated } \\
\left(20^{\circ} \mathrm{C}\right)\end{array}$ & $\mathrm{C} 1$ & 12 & - & 58 & - & - \\
\hline $\begin{array}{l}\text { Un-heated } \\
\left(20^{\circ} \mathrm{C}\right)\end{array}$ & $\mathrm{C} 2$ & 13 & - & 55 & - & - \\
\hline $\begin{array}{l}\text { Post-heated } \\
\left(500^{\circ} \mathrm{C}\right)\end{array}$ & $\mathrm{C} 3$ & 12 & 2 & 52 & 22 & 3.4 \\
\hline $\begin{array}{l}\text { Post-heated } \\
\left(500^{\circ} \mathrm{C}\right)\end{array}$ & $\mathrm{C} 4$ & 12 & 2 & 53 & 22 & 3.4 \\
\hline $\begin{array}{l}\text { Post-heated } \\
\left(500^{\circ} \mathrm{C}\right)\end{array}$ & $\mathrm{C} 5$ & 14 & 2 & 52 & 24 & 3.6 \\
\hline $\begin{array}{l}\text { Post-heated } \\
\left(500^{\circ} \mathrm{C}\right)\end{array}$ & C6 & 19 & 4 & 51 & 22 & 3.7 \\
\hline $\begin{array}{l}\text { Post-heated } \\
\left(500^{\circ} \mathrm{C}\right)\end{array}$ & C7 & 11 & 2 & 53 & 22 & 3.8 \\
\hline $\begin{array}{l}\text { Post-heated } \\
\left(500^{\circ} \mathrm{C}\right)\end{array}$ & $\mathrm{C} 8$ & 14 & 2 & 54 & 23 & 3.8 \\
\hline $\begin{array}{l}\text { Post-heated } \\
\left(500^{\circ} \mathrm{C}\right)\end{array}$ & C9 & 14 & 5 & 53 & 21 & 3.8 \\
\hline $\begin{array}{l}\text { Un-heated } \\
\left(20^{\circ} \mathrm{C}\right)\end{array}$ & $\mathrm{C} 10$ & 19 & - & 56 & - & - \\
\hline $\begin{array}{l}\text { Un-heated } \\
\left(20^{\circ} \mathrm{C}\right)\end{array}$ & C11 & 19 & - & 57 & - & - \\
\hline $\begin{array}{l}\text { Post-heated } \\
\left(500^{\circ} \mathrm{C}\right)\end{array}$ & $\mathrm{C} 12$ & 16 & 4 & 52 & 25 & 3.7 \\
\hline $\begin{array}{l}\text { Post-heated } \\
\left(500^{\circ} \mathrm{C}\right)\end{array}$ & $\mathrm{C} 13$ & 16 & 4 & 53 & 25 & 3.7 \\
\hline $\begin{array}{l}\text { Post-heated } \\
\left(500^{\circ} \mathrm{C}\right)\end{array}$ & $\mathrm{C} 14$ & 14 & 4 & 54 & 24 & 3.7 \\
\hline $\begin{array}{l}\text { Post-heated } \\
\left(500^{\circ} \mathrm{C}\right)\end{array}$ & C15 & 14 & 4 & 53 & 24 & 3.7 \\
\hline $\begin{array}{l}\text { Post-heated } \\
\left(500^{\circ} \mathrm{C}\right)\end{array}$ & $\mathrm{C} 16$ & 16 & 2 & 52 & 22 & 3.7 \\
\hline $\begin{array}{l}\text { Post-heated } \\
\left(500{ }^{\circ} \mathrm{C}\right)\end{array}$ & $\mathrm{C} 17$ & 18 & 10 & 53 & 22 & 3.7 \\
\hline \multicolumn{4}{|c|}{$\begin{array}{l}\text { Average Compressive Strength } \\
\text { Standard Deviation }\end{array}$} & $\begin{array}{l}54 \\
\pm 1.9\end{array}$ & $\begin{array}{l}23 \\
\pm 1.3\end{array}$ & $\begin{array}{l}3.7 \\
\pm 0.13\end{array}$ \\
\hline \multicolumn{4}{|c|}{$\begin{array}{l}\text { Average Compressive Strength Percentage } \\
\text { Loss }\end{array}$} & $57.0 \%$ & & \\
\hline
\end{tabular}

lected between the spacing of the link bars and the main longitudinal reinforcement. The cubes and columns were placed in an electric furnace after measuring the ultrasonic pulse velocity values, and heated up to the temperatures as described previously in Sections 3.1 and 3.2. The pulse velocity values were again measured for the post-heated concrete cubes and post-heated reinforced concrete columns, on the 7th day of cooling in air after exposing to the specified temperatures, at the same positions where the readings were taken before heating.

\section{Test results and discussions}

\subsection{Residual compressive strength}

The post-heated concrete cubes on the 7th day of cooling in air after heating to $200{ }^{\circ} \mathrm{C}, 300{ }^{\circ} \mathrm{C}, 450{ }^{\circ} \mathrm{C}, 500{ }^{\circ} \mathrm{C}$ and $550{ }^{\circ} \mathrm{C}$ were then tested in a compression testing machine. The variability of data and average values of residual compressive strength obtained from all 


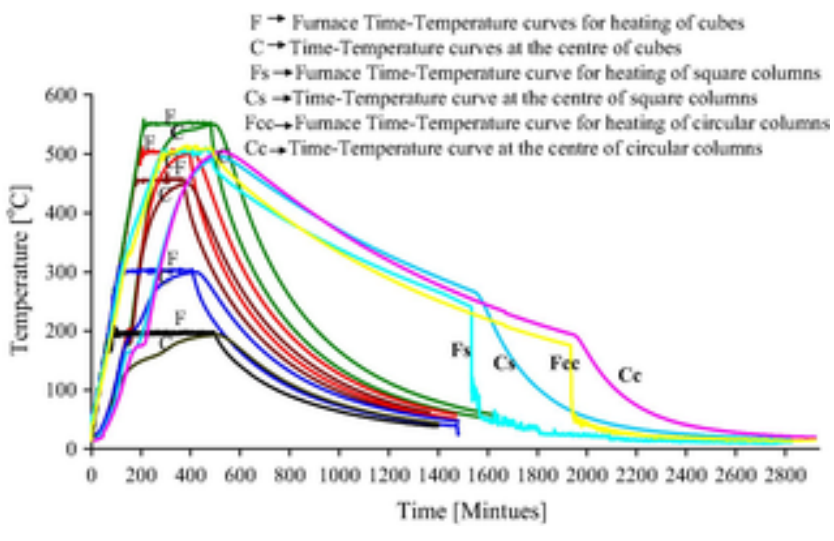

Fig. 4. Time-Temperature curves for Cubes and Columns Exposed to Various Temperatures.

compressive strength tests of the concrete cubes on the 7 th day of cooling in air after exposing to various high temperatures are shown in Figs. 5 and 6. The results of the ultimate axial compressive strength and the residual compressive strength of the un-heated and the postheated cubes exposed to various temperatures are shown in Tables 3 and 4 . The residual compressive strength was calculated as the percentage compressive strength of post-heated concrete cubes with respect to the corresponding un-heated concrete cubes.

In this experimental work, all specimens were tested at room temperature after cooling down without any application of compressive load at the time of heating or cooling. Since the strength reduction in unstressed concrete after cooling is greater than stressed and unstressed concrete at elevated temperature [3], it is argued that the unstressed residual strength test is more conservative for assessing the post-fire or residual properties of concrete [3,18-20]. For the cubes heated to $450{ }^{\circ} \mathrm{C}, 500{ }^{\circ} \mathrm{C}$ and $550{ }^{\circ} \mathrm{C}$, both the $100 \mathrm{~mm}$ and $150 \mathrm{~mm}$ concrete cubes were tested to investigate the effect of specimen size. It was found that the residual compressive strength of post-heated cubes with different size had no evident difference, as shown in Table 4, which supports the previous findings of Arioz [22].

It can be seen from Fig. 6 and Table 4 that the residual unstressed compressive strength reduced slightly up to temperatures of $300{ }^{\circ} \mathrm{C}$. Above $450{ }^{\circ} \mathrm{C}$ it dropped sharply. This is due to the fact that above $450{ }^{\circ} \mathrm{C}$, the calcium silicate begins to decompose into quick lime and silica. This process is irreversible and there is a progressive loss of strength [23]. The residual compressive strength on the 7 th day of cooling in air after heating to $200{ }^{\circ} \mathrm{C}, 300{ }^{\circ} \mathrm{C}, 450{ }^{\circ} \mathrm{C}, 500{ }^{\circ} \mathrm{C}$ and $550{ }^{\circ} \mathrm{C}$ was found to be $80 \%, 76 \%, 60 \%, 47 \%$ and $30 \%$ respectively, as shown in Fig. 6 and Table 4.

It is worth highlighting that the residual compressive strength of the $100 \mathrm{~mm}$ cubes for the square and circular columns subjected to $500{ }^{\circ} \mathrm{C}$ temperature was further reduced by approximately $8 \%$ when

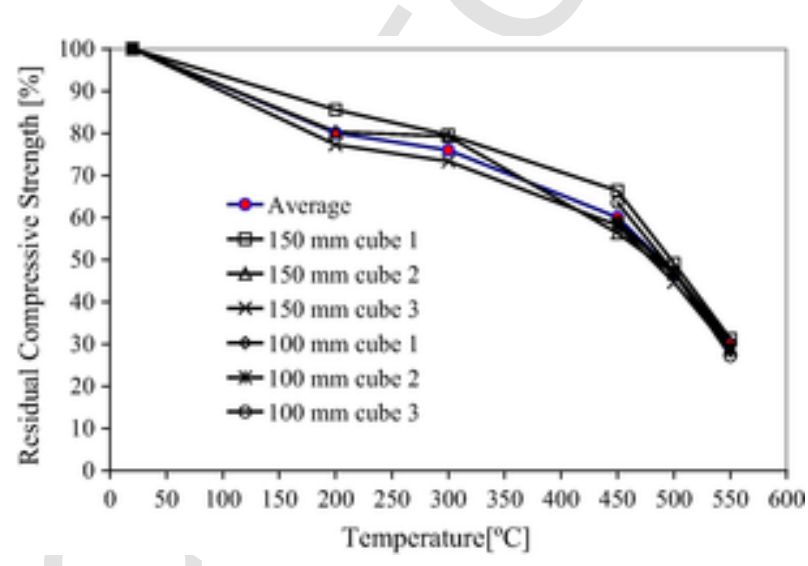

Fig. 5. Variability of data showing the effect of temperature on residual compressive strength.

Table 3

Ultimate Compressive Strength and Moisture Content.

\begin{tabular}{|c|c|c|c|c|c|c|c|c|c|c|c|c|c|c|c|c|}
\hline \multirow{3}{*}{$\begin{array}{l}\text { Test conditions } \\
\text { Un-heated }\left(20^{\circ} \mathrm{C}\right)\end{array}$} & \multicolumn{8}{|c|}{ Ultimate Compressive Strength [MPa] } & \multicolumn{8}{|c|}{ Moisture Content } \\
\hline & \multicolumn{3}{|c|}{$150 \mathrm{~mm}$ Cubes } & \multicolumn{3}{|c|}{$100 \mathrm{~mm}$ Cubes } & \multirow{2}{*}{$\begin{array}{l}\text { Average } \\
54.0\end{array}$} & \multirow{2}{*}{$\begin{array}{l}\text { STDEVA } \\
\pm 1.49\end{array}$} & \multicolumn{3}{|c|}{$150 \mathrm{~mm}$ Cubes } & \multicolumn{3}{|c|}{$100 \mathrm{~mm}$ Cubes } & \multirow{2}{*}{$\begin{array}{l}\text { Average } \\
-\end{array}$} & \multirow{2}{*}{$\frac{\text { STDEVA }}{-}$} \\
\hline & 51.60 & 53.55 & 53.85 & 54.24 & 56.27 & 54.09 & & & - & - & - & - & - & - & & \\
\hline Post-heated $\left(200^{\circ} \mathrm{C}\right)$ & 44.15 & 43.03 & 41.61 & - & - & - & 43.0 & \pm 1.27 & 3.6 & 3.5 & 3.6 & - & - & - & 3.6 & \pm 0.06 \\
\hline Post-heated $\left(300^{\circ} \mathrm{C}\right)$ & 41.08 & 42.42 & 39.49 & - & - & - & 41.0 & \pm 1.47 & 3.5 & 3.4 & 3.3 & - & - & - & 3.4 & \pm 0.10 \\
\hline Post-heated $\left(450^{\circ} \mathrm{C}\right)$ & 34.24 & 30.14 & 31.30 & 31.98 & 33.08 & 34.31 & 32.5 & \pm 1.67 & 3.7 & 3.8 & 3.6 & 3.7 & 3.5 & 3.4 & 3.7 & \pm 0.15 \\
\hline Post-heated $\left(500^{\circ} \mathrm{C}\right)$ & 25.36 & 24.98 & 24.06 & 25.63 & 26.31 & 25.48 & 25.5 & \pm 0.75 & 3.8 & 3.8 & 3.6 & 3.7 & 3.6 & 3.7 & 3.8 & \pm 0.09 \\
\hline Post-heated $\left(550^{\circ} \mathrm{C}\right)$ & 16.11 & 15.58 & 15.32 & 16.51 & 16.12 & 14.67 & 16.0 & \pm 0.67 & 3.6 & 3.7 & 3.6 & 3.5 & 3.6 & 3.6 & 3.6 & \pm 0.06 \\
\hline
\end{tabular}


Table 4

Residual Axial Compressive Strength, and Pulse Velocity.

\begin{tabular}{|c|c|c|c|c|c|c|c|c|c|c|c|c|c|c|c|c|}
\hline \multirow{3}{*}{$\begin{array}{l}\text { Test conditions } \\
\text { Un-heated }\left(20^{\circ} \mathrm{C}\right)\end{array}$} & \multicolumn{8}{|c|}{ Residual Compressive Strength (\%) } & \multicolumn{8}{|c|}{ Pulse Velocity [km/s] } \\
\hline & \multicolumn{3}{|c|}{$150 \mathrm{~mm}$ Cubes } & \multicolumn{3}{|c|}{$100 \mathrm{~mm}$ Cubes } & \multirow{2}{*}{$\begin{array}{l}\text { Average } \\
100\end{array}$} & \multirow{2}{*}{$\begin{array}{l}\text { STDEVA } \\
\pm 0\end{array}$} & \multicolumn{3}{|c|}{$150 \mathrm{~mm}$ Cubes } & \multicolumn{3}{|c|}{$100 \mathrm{~mm}$ Cubes } & \multirow{2}{*}{$\frac{\text { Average }}{4.6}$} & \multirow{2}{*}{$\frac{\text { STDEVA }}{ \pm 0.05}$} \\
\hline & 100 & 100 & 100 & 100 & 100 & 100 & & & 4.59 & 4.59 & 4.59 & 4.68 & 4.68 & 4.68 & & \\
\hline Post-heated $\left(200^{\circ} \mathrm{C}\right)$ & 85.56 & 80.35 & 77.27 & - & - & - & 80 & \pm 4.19 & 4.20 & 4.09 & 4.0 & - & - & - & 4.1 & \pm 0.10 \\
\hline Post-heated $\left(300{ }^{\circ} \mathrm{C}\right)$ & 79.61 & 79.21 & 73.33 & - & - & - & 76 & \pm 3.52 & 3.95 & 3.95 & 3.95 & - & - & - & 3.9 & \pm 0.0000 \\
\hline Post-heated $\left(450{ }^{\circ} \mathrm{C}\right)$ & 66.36 & 56.28 & 58.14 & 58.96 & 58.79 & 63.49 & 60 & \pm 3.79 & 2.99 & 2.98 & 2.98 & 2.99 & 3.03 & 3.03 & 3.0 & \pm 0.02 \\
\hline Post-heated $\left(500{ }^{\circ} \mathrm{C}\right)$ & 49.15 & 46.65 & 44.68 & 47.25 & 46.76 & 47.11 & 47 & \pm 1.43 & 2.20 & 2.20 & 2.20 & 2.4 & 2.4 & 2.4 & 2.3 & \pm 0.11 \\
\hline Post-heated $\left(550^{\circ} \mathrm{C}\right)$ & 31.22 & 29.09 & 28.45 & 30.44 & 28.65 & 27.12 & 30 & \pm 1.47 & $1.02^{*}$ & $0.98^{*}$ & $0.94^{*}$ & $1.18^{*}$ & $1.18^{*}$ & $1.18^{*}$ & $1.1^{*}$ & \pm 0.11 \\
\hline
\end{tabular}

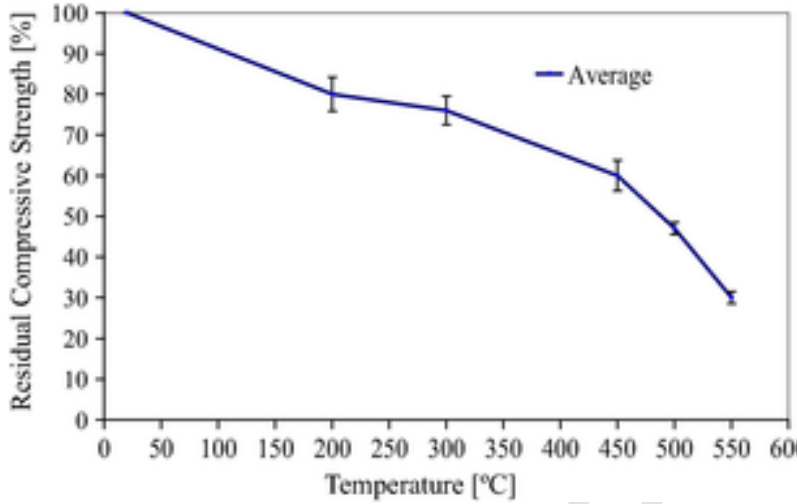

Fig. 6. Relationship between temperature and average values of residual compressive strength (with error bars on Y-axis).

tested mostly after $2-3$ months of cooling in air, as shown in Tables 1 and 2. This is due to the fact that for 2-3 months exposure to air, the quicklime (calcium oxide) absorbed moisture and converted to slaked lime (calcium hydroxide) resulting in more cracking and a reduction in residual compressive strength of concrete [24-26]. No evidence of any visible cracks was found in the cubes subjected to temperatures in the range of $200-450^{\circ} \mathrm{C}$. However, minor cracks were found when the cubes were subjected to a temperature of $500{ }^{\circ} \mathrm{C}$. At $550{ }^{\circ} \mathrm{C}$ significant visible cracks were seen on the surface of all cubes.

\subsection{Ultrasonic pulse velocity}

\subsubsection{Cubes}

Pulse velocity measurements made on cubes have the advantage that they relate pulse velocity values directly to the concrete in the reinforced concrete columns. Figs. 7 and 8 show the variability of data and the average values of pulse velocity measurements made on concrete cubes on the 7th day of cooling in air after exposing to temperatures ranging from $20^{\circ} \mathrm{C}$ to $550{ }^{\circ} \mathrm{C}$. Each data point in Fig. 8 represents the average of ultrasonic pulse velocities. The ultrasonic pulse velocities on the 7 th day of cooling in air after heating to $200{ }^{\circ} \mathrm{C}, 300{ }^{\circ} \mathrm{C}, 450{ }^{\circ} \mathrm{C}, 500{ }^{\circ} \mathrm{C}$ and $550{ }^{\circ} \mathrm{C}$ were found to be $4.1 \mathrm{~km} /$ $\mathrm{s}, 3.9 \mathrm{~km} / \mathrm{s}, 3 \mathrm{~km} / \mathrm{s}, 2.3 \mathrm{~km} / \mathrm{s}$ and $1.1 \mathrm{~km} / \mathrm{s}$ respectively, as shown in

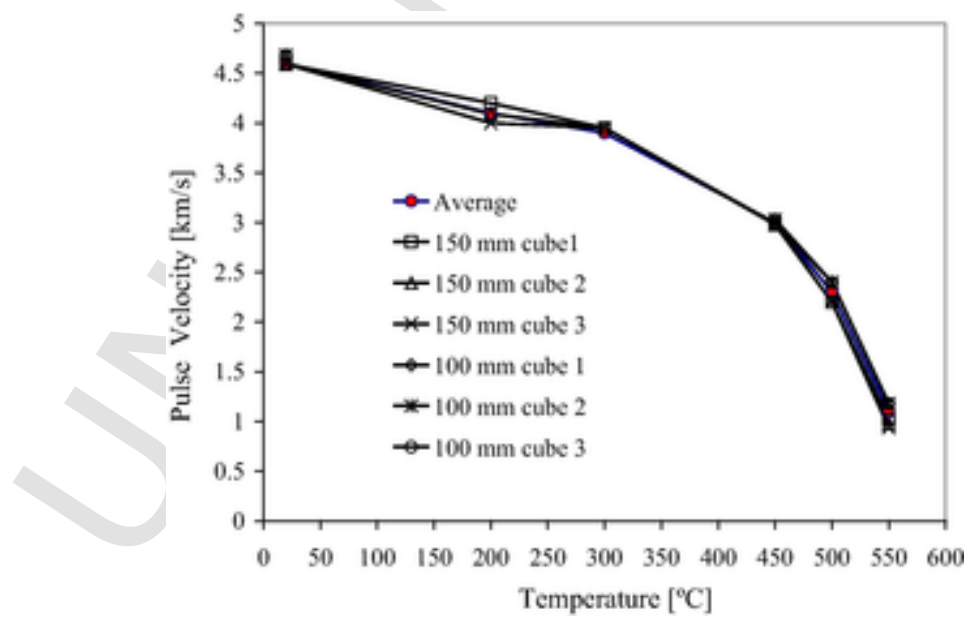

Fig. 7. Variability of data showing the effect of temperature on pulse velocity. 


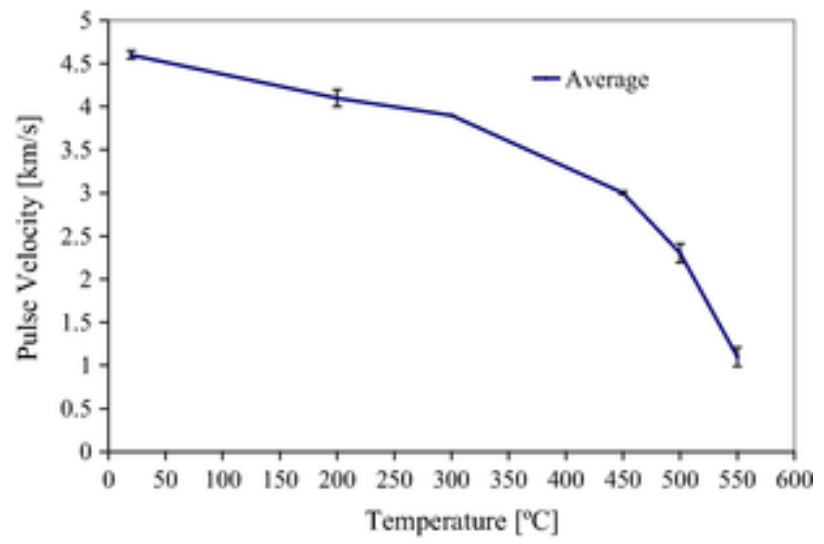

Fig. 8. Relationship between temperature and average values of pulse velocity (with error bars on Y-axis).

Fig. 8 and Table 4. From Fig. 8 it can be seen that the ultrasonic pulse velocity of the post-heated concrete decreases markedly with increasing temperature and the reduction in ultrasonic pulse velocity is notable above heated temperatures of $450^{\circ} \mathrm{C}$. It is worth mentioning that there are very low pulse velocity values which are marked with a star in Table 4. This was due to the development of extensive cracks in the post-heated concrete preventing the propagation of the pulse velocity, which resulted in low values $[12,27]$. Comparing Figs 6 and 8 it can be seen that the trend of reduction in the pulse velocity is similar to the observed reduction of the residual compressive strength of concrete.

\subsubsection{Columns}

The measured ultrasonic pulse velocities for the un-heated and post-heated columns and their corresponding cubes are shown in Tables 5 and 6 . The pulse velocity values were measured at the middle and at the top position of the columns ( $75 \mathrm{~mm}$ below the top edge of column) and at the middle position of the cubes. Each value presented in the tables represents the average of three readings taken at the specified position. Tables 5 and 6 show that the values of the ultrasonic pulse velocities measured at the middle position of both the post-heated square and circular columns were slightly lower than the values measured at the top position of the columns $(75 \mathrm{~mm}$ below the top edge of column). This could be due to more cracking in the middle compared to the top position of the columns. The measured values of the ultrasonic pulse velocities in the post-heated circular columns were slightly lower than the post-heated square columns. This is likely due to more cracking in the circular than the square columns.

\subsection{Relation between residual compressive strength and ultrasonic pulse velocity}

Figs. 9 and 10 demonstrate the relationship between the ultrasonic pulse velocity and the residual compressive strength of the concrete cubes (cast from the same batch of concrete mix used for casting the reinforced concrete columns) measured on the 7 th day of cooling in air after being subjected to temperatures ranging from $20^{\circ} \mathrm{C}$ to $550{ }^{\circ} \mathrm{C}$. The results of residual axial compressive strength and the measured values of ultrasonic pulse velocity of cubes after exposing to the temperatures ranging from $20{ }^{\circ} \mathrm{C}$ to $550{ }^{\circ} \mathrm{C}$ are shown in Table 4 .

It is also obvious from Fig. 4 that during the heating, the temperatures at the centre of cross-section of concrete cubes are generally remain comparatively low compared to the furnace temperatures up to the specified target furnace temperatures of $200^{\circ} \mathrm{C}, 300^{\circ} \mathrm{C}, 450^{\circ}$
Table 5

Pulse Velocity Measurements in Un-Heated and Post-Heated Square Columns and Associated Cubes.

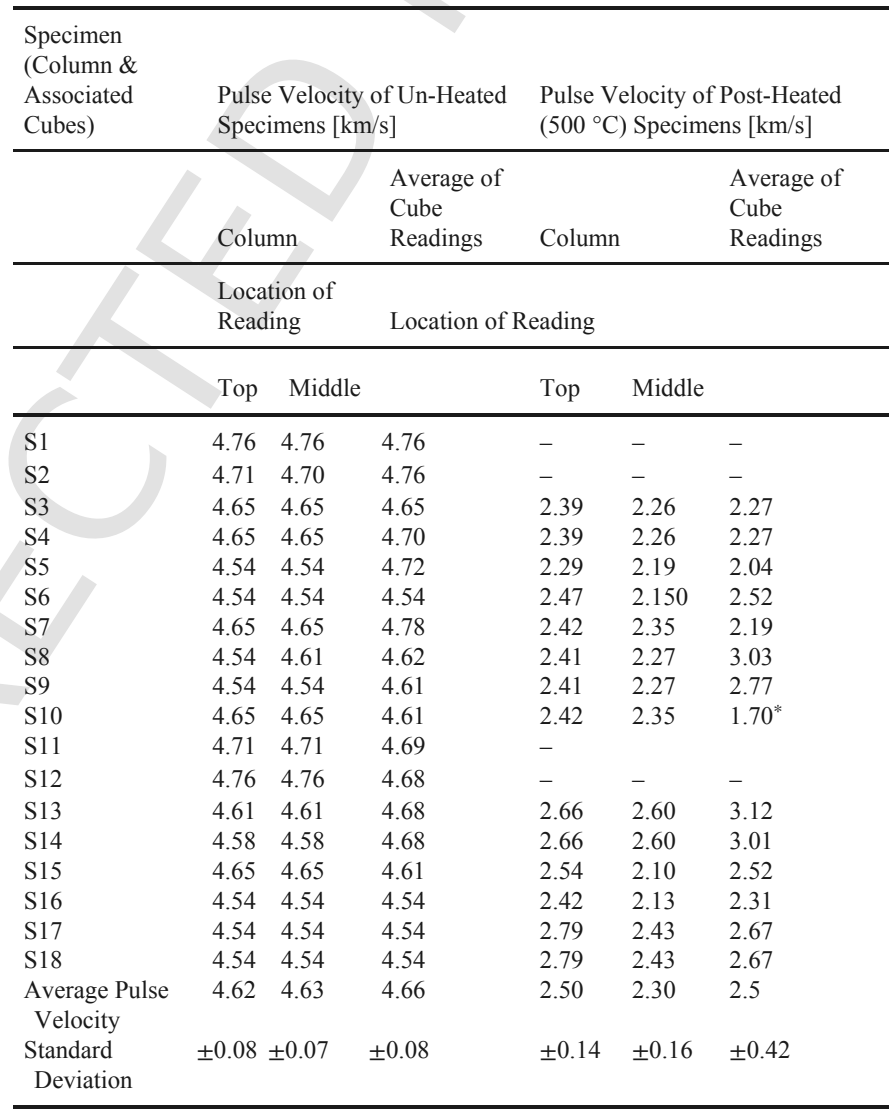

$\mathrm{C}, 500{ }^{\circ} \mathrm{C}$ or $550{ }^{\circ} \mathrm{C}$. The difference of temperatures produces the thermal gradient. The development of thermal gradient during the heating phase when the average furnace temperatures reached at the specified target temperatures of $200{ }^{\circ} \mathrm{C}, 300{ }^{\circ} \mathrm{C}, 450{ }^{\circ} \mathrm{C}, 500{ }^{\circ} \mathrm{C}$ or $550{ }^{\circ} \mathrm{C}$, represents the real fire scenario of non-uniform heating of concrete. However, after reaching the average furnace temperatures at the specified temperatures of $200{ }^{\circ} \mathrm{C}, 300{ }^{\circ} \mathrm{C}, 450{ }^{\circ} \mathrm{C}, 500{ }^{\circ} \mathrm{C}$ or $550{ }^{\circ} \mathrm{C}$, the furnace temperatures remain constant until the temperatures at the centre of the cubes reached the same specified temperatures. The delaying stage in attaining complete uniformity of tem- 


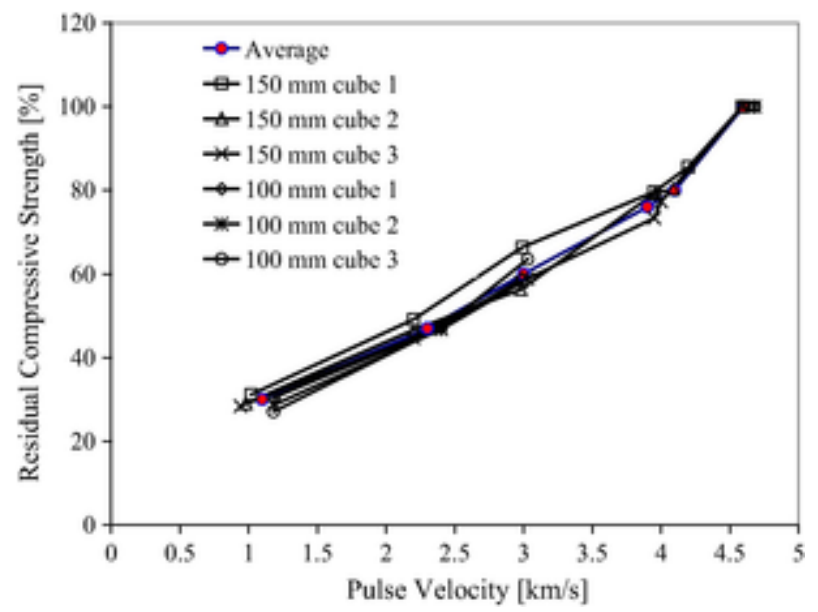

Fig. 9. Variability of data showing the relationship between residual compressive strength and pulse velocity.

peratures throughout the cross-section represents the worst-case scenario of fire (in terms of longer period of exposure to temperatures).

The axial compression tests at ambient temperature are carried out for each concrete cube after exposing to uniform heating ranging from $20^{\circ} \mathrm{C}$ to $550{ }^{\circ} \mathrm{C}$ temperatures. This is the most conservative approach to evaluate the in-situ residual compressive strength of fire damaged repairable concrete. In a real fire, the peak external temperatures greater than $900{ }^{\circ} \mathrm{C}$ are frequent during fires within the buildings, but as reported previously; the reduction of residual compressive strength of concrete mainly depends upon the peak internal temperatures reached within the cross sections of the structural members during the fire. Therefore, in the present reported study, the peak internal temperatures $300{ }^{\circ} \mathrm{C}-550{ }^{\circ} \mathrm{C}$ (within the cross sections) are considered the worst-case scenario for the fire damaged repairable concrete structures.

The compressive strength of un-heated and post-heated cubes represents the in-situ compressive strength of concrete for un-heated and post-heated reinforced concrete columns. From Tables 5 and 6, it can be seen that the pulse velocity values for un-heated cubes and columns were the same. However, the pulse velocity values for the cubes on the 7 th day of cooling in air subjected to $500{ }^{\circ} \mathrm{C}$ were slightly higher than the pulse velocity values of square and circular columns on the 7 th day of cooling in air subjected to $500{ }^{\circ} \mathrm{C}$. This could be due to more micro cracking in post-heated columns.
It is also evident from Tables 4-6 that approximately the same ultrasonic pulse velocities values were found in $100 \mathrm{~mm}, 150 \mathrm{~mm}$ plain concrete cubes, $200 \mathrm{~mm}$ square and $200 \mathrm{~mm}$ diameter circular reinforced concrete columns at ambient and after subjecting the elements to $500{ }^{\circ} \mathrm{C}$. This indicates that the ultrasonic pulse velocity was not affected by the size, shape of specimen and the presence of longitudinal reinforcement transverse to the ultrasonic pulse velocity measuring path.

\subsection{Evaluation of in-situ residual compressive strength of concrete in post-heated reinforced concrete columns}

Measuring directly the ultrasonic pulse velocities from the surface of existing fire damaged reinforced concrete columns, without extracting concrete cores and estimating the maximum fire intensity and duration of fire; it is easier to evaluate the in-situ residual compressive strength of post-heated concrete. It is important to highlight that the developed relationship between the ultrasonic pulse velocity and the residual compressive strength (see Fig. 10 and Table 7) is applicable to both for the cases whether the columns are uniformly heated (the worst-case scenario of fire) to a single temperature throughout the cross section or non-uniformly heated to the temperatures ranging from $20{ }^{\circ} \mathrm{C}$ to $550{ }^{\circ} \mathrm{C}$ within the cross section (which emulate the temperature distribution within the cross section). The ultrasonic pulse velocity will always tend to a single value (but it will

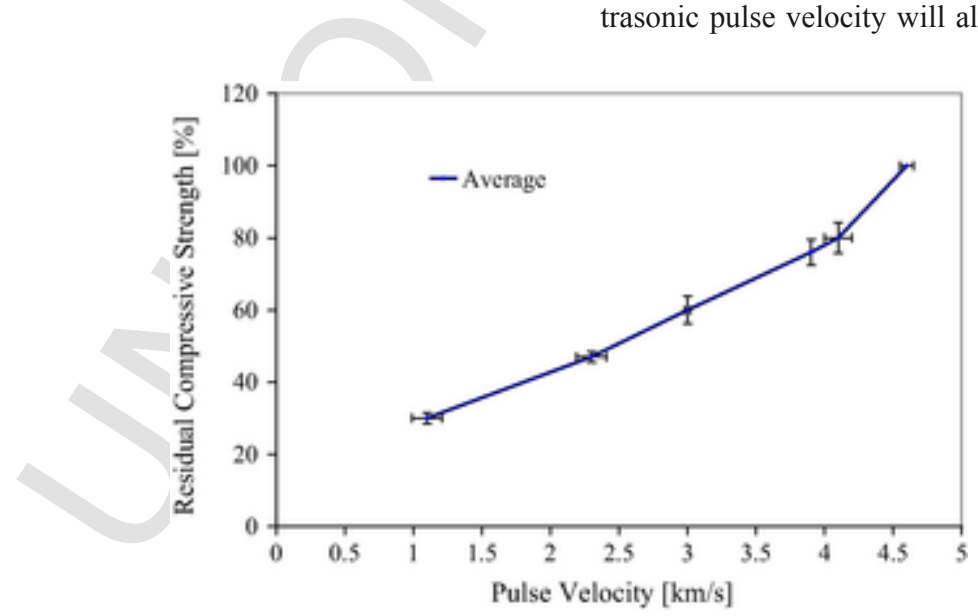

Fig. 10. Relationship between average values of residual compressive strength (with error bars on $\mathrm{Y}$-axis) and average values of pulse velocity (with error bars on X-axis). 
Table 7

Evaluation of residual compressive strength of concrete in fire damaged reinforced concrete columns.

Reinstatement

Evaluation of Residual Compressive Strength of Concrete in Fire Damaged Reinforced Concrete Columns

\begin{tabular}{|c|c|c|c|}
\hline $\begin{array}{l}\text { Ultrasonic Pulse } \\
\text { Velocity }(\mathrm{km} / \mathrm{s})\end{array}$ & $\begin{array}{l}\text { Residual } \\
\text { Compressive } \\
\text { Strength of } \\
\text { Concrete }(\%)\end{array}$ & $\begin{array}{l}\text { Quality of } \\
\text { Residual } \\
\text { Concrete }\end{array}$ & $\begin{array}{l}\text { Reinstatement or Demolition } \\
\text { Status }\end{array}$ \\
\hline $4.6-4.1$ & $\begin{array}{l}100-80 \% \text { of its } \\
\text { original } \\
\text { undamaged } \\
\text { value }\end{array}$ & Very Good & Reinstatement \\
\hline \multicolumn{4}{|l|}{$\begin{array}{l}4.1-3.980-76 \% \\
\text { of its original } \\
\text { undamaged } \\
\text { valueGood }\end{array}$} \\
\hline $3.9-3$ & $\begin{array}{l}76-60 \% \text { of its } \\
\text { original } \\
\text { undamaged } \\
\text { value }\end{array}$ & Satisfactory & $\begin{array}{l}\text { Reinstatement or Demolition } \\
\text { More possibility of repairing } \\
\text { than demolishing(the decision } \\
\text { would be based on the overall } \\
\text { in-situ site condition of } \\
\text { damages) }\end{array}$ \\
\hline $3-2.3$ & $\begin{array}{l}60-47 \% \text { of its } \\
\text { original } \\
\text { undamaged } \\
\text { value }\end{array}$ & Poor & $\begin{array}{l}\text { Reinstatement or Demolition } \\
\text { Worst-Case Scenario Less } \\
\text { possibility of repairing than } \\
\text { demolishing(the decision } \\
\text { would be based on the overall } \\
\text { in-situ site condition of } \\
\text { damages) }\end{array}$ \\
\hline $2.3-1.1$ & $\begin{array}{l}47-30 \% \text { of its } \\
\text { original } \\
\text { undamaged } \\
\text { value }\end{array}$ & Very Poor & Demolition \\
\hline
\end{tabular}

not be similar) within the range of $4.6 \mathrm{~km} / \mathrm{s}-1.1 \mathrm{~km} / \mathrm{s}$ both for the cases whether the columns are uniformly heated to a single temperature (the most worst-case scenario of fire) or non-uniformly heated to the temperatures ranging from $20{ }^{\circ} \mathrm{C}$ to $550{ }^{\circ} \mathrm{C}$ within the cross section. However, the measuring value of ultrasonic pulse velocity would be lesser in case of uniformly heated columns than the non-uniformly heated columns.

Similarly, corresponding to the single value of pulse velocity, the residual compressive strength will always tend to a single value (but it will not be similar) within the range of $100 \%-30 \%$ of its original unheated compressive strength both for the cases whether the columns are uniformly heated to a single temperature (theworst-case scenario of fire) or non-uniformly heated to temperatures ranging from $20{ }^{\circ} \mathrm{C}$ to $550{ }^{\circ} \mathrm{C}$ within the cross section. However, the value of residual compressive strength would be lower in case of uniformly heated columns as compared to the non-uniformly heated columns.
It is also noticeable from Fig. 10 and Table 7 that the in-situ compressive strength of concrete is in excellent condition for the ultrasonic pulse velocity of about $4.6 \mathrm{~km} / \mathrm{s}$. The in-situ residual cube compressive strength value for such condition of concrete would be considered $100 \%$ of its original un-damaged tested value (approximately $54 \mathrm{MPa}$ ). The ultrasonic pulse velocity values ranging from $4.6 \mathrm{~km} /$ $\mathrm{s}$ to $4.1 \mathrm{~km} / \mathrm{s}$ indicate that the compressive strength of concrete in the fire damaged concrete column is in very good condition and its residual value would be considered in the range of $100 \%-80 \%$ of its original un-damaged value. The ultrasonic pulse velocity value falling within the range $4.1 \mathrm{~km} / \mathrm{s}$ to $3.9 \mathrm{~km} / \mathrm{s}$ shows that the compressive strength of concrete in the fire damaged concrete column is in good condition and its residual value would be considered within the range of $80 \%-76 \%$ of its original un-damaged value.

For the pulse velocity values ranging from $3.9 \mathrm{~km} / \mathrm{s}$ to $3 \mathrm{~km} / \mathrm{s}$, the in-situ compressive strength of concrete in the fire damaged concrete column would be considered in satisfactory condition. The residual compressive strength for such condition of concrete would be considered in the range of $76 \%-60 \%$ of its original un-damaged value. If the ultrasonic pulse velocity value falls within the range of $3 \mathrm{~km} / \mathrm{s}$ to $2.3 \mathrm{~km} / \mathrm{s}$, the compressive strength of fire damaged concrete would be considered poor and its residual value would be taken in the range of about $60 \%-47 \%$ of its original un-damaged value. However, the ultrasonic pulse velocity values falling in the range of $2.3 \mathrm{~km} / \mathrm{s}-1.1 \mathrm{~km} /$ $\mathrm{s}$ indicate that the quality of concrete is very poor with the residual in-situ compressive strength ranging from $30 \%$ to $47 \%$ of its original un-damaged value.

\subsection{Evaluation of ultimate axial compressive strength of reinforced concrete columns}

The axial load resistance of a reinforced concrete column is equal to the sum of the concrete compressive strength resistance and the resistance provided by the longitudinal reinforcing bars. The reinforced concrete columns in this study were exposed to the maximum temperature $500{ }^{\circ} \mathrm{C}$, as described earlier in Section 3.2, and hot rolled reinforcing bars were used to reinforce the columns. It is well known that, the residual yield strength of reinforcing bars after cooling is completely recovered to the original level when heated up to $600{ }^{\circ} \mathrm{C}$ for hot rolled steel [4]. Therefore, the residual yield strength of reinforcing bars used in this study remained un-affected when exposed to the maximum temperature $500^{\circ} \mathrm{C}$.

The theoretical ultimate or nominal strength values of the reinforced concrete square and circular columns shown in Tables 8 and 9 were calculated based on the American Concrete Institute (ACI Committee 318-11 Cl.10.3.6) [28], Canadian Standard Association (CSA 23.3.Cl 10.10.4) [29], Eurocode 2: (BSEN1992-1-1; Cl.3.1.7) [30] and British Standard BS 8110 [31]. The differences between the ul-

Table 8

Theoretical and Experimental Values of Ultimate Axial Compressive Strength of Square Columns.

\begin{tabular}{|c|c|c|c|c|c|c|c|c|c|c|}
\hline \multirow[t]{3}{*}{ Test Conditions } & \multicolumn{10}{|c|}{ Ultimate Axial Compressive Strength of Square Columns (kN) } \\
\hline & \multicolumn{6}{|l|}{ Theoretical } & \multicolumn{4}{|c|}{ Experimental } \\
\hline & ACI Code & B.S Code & Euro Code & Canadian Code & Average & STDEVA & Test-1 & Test-2 & Average & STDEVA \\
\hline Un-heated $\left(20^{\circ} \mathrm{C}\right)$ & 1853 & 1772 & 1764 & 1733 & 1781 & \pm 51 & $1930(\mathrm{~S} 1)$ & $2000(\mathrm{~S} 2)$ & 1965 & \pm 49 \\
\hline Post-heated $\left(200^{\circ} \mathrm{C}\right)$ & 1546 & 1482 & 1475 & 1470 & 1493 & \pm 36 & - & - & - & - \\
\hline Post-heated $\left(300^{\circ} \mathrm{C}\right)$ & 1490 & 1429 & 1423 & 1421 & 1441 & \pm 33 & - & - & - & - \\
\hline Post-heated $\left(450^{\circ} \mathrm{C}\right)$ & 1253 & 1205 & 1200 & 1210 & 1217 & \pm 24 & - & - & - & - \\
\hline Post-heated $\left(500{ }^{\circ} \mathrm{C}\right)$ & 1058 & 1020 & 1016 & 1032 & 1032 & \pm 19 & 1099 (S4) & $1121(\mathrm{~S} 3)$ & 1110 & \pm 16 \\
\hline Post-heated $\left(550^{\circ} \mathrm{C}\right)$ & 793 & 769 & 767 & 783 & 778 & \pm 12 & - & - & - & - \\
\hline
\end{tabular}


Table 9

Theoretical and Experimental Values of Ultimate Axial Compressive Strength of Circular Columns.

\begin{tabular}{|c|c|c|c|c|c|c|c|c|c|c|}
\hline \multirow[t]{3}{*}{ Test Conditions } & \multicolumn{10}{|c|}{ Ultimate Axial Compressive Strength of Circular Columns (kN) } \\
\hline & \multicolumn{6}{|l|}{ Theoretical } & \multicolumn{4}{|c|}{ Experimental } \\
\hline & ACI Code & B.S Code & Euro Code & Canadian Code & Average & STDEVA & Test-1 & Test-2 & Average & STDEVA \\
\hline Un-heated $\left(20^{\circ} \mathrm{C}\right)$ & 1444 & 1381 & 1374 & 1350 & 1387 & \pm 40 & $1439(\mathrm{C} 1)$ & $1397(\mathrm{C} 2)$ & 1418 & \pm 30 \\
\hline Post-heated $\left(200^{\circ} \mathrm{C}\right)$ & 1203 & 1152 & 1147 & 1143 & 1161 & \pm 28 & - & - & - & - \\
\hline Post-heated $\left(300^{\circ} \mathrm{C}\right)$ & 1159 & 1111 & 1106 & 1105 & 1120 & \pm 26 & - & - & - & - \\
\hline Post-heated $\left(450^{\circ} \mathrm{C}\right)$ & 973 & 935 & 931 & 939 & 945 & \pm 19 & - & - & - & - \\
\hline Post-heated $\left(500{ }^{\circ} \mathrm{C}\right)$ & 819 & 789 & 786 & 798 & 798 & \pm 15 & $826(\mathrm{C} 3)$ & - & 826 & - \\
\hline Post-heated $\left(550^{\circ} \mathrm{C}\right)$ & 611 & 592 & 590 & 603 & 599 & \pm 10 & - & - & - & - \\
\hline
\end{tabular}

timate strength values for different codes shown in Tables 8 and 9 were due to different factors of compressive stress values as explained in detail in the following calculation steps.

The American Concrete Institute (ACI Committee 318-11 Cl.10.3.6) [28]

1) The theoretical ultimate strength or nominal strength values were computed using the following ACI equation.

$$
P_{n}=0.85 \times f_{c}^{\prime} \times\left(A_{g}-A_{s t}\right)+f_{y} \times A_{s t}
$$

\section{2) Canadian Standard Association (CSA 23.3.Cl 10.10.4) [29]}

The theoretical ultimate strength or nominal strength values were computed using the following Canadian Standard Association code equation.

$$
\begin{aligned}
& P_{n}=\alpha \times f_{c}^{\prime} \times\left(A_{g}-A_{s t}\right)+f_{y} \times A_{s t} \\
& \alpha=0.85-0.0015 \times f_{c}^{\prime} \geqslant 0.67
\end{aligned}
$$

3) Eurocode 2: (BSEN1992-1-1; Cl.3.1.7) [30]

The theoretical ultimate strength or nominal strength values were computed using the following Eurocode 2 equation.

$$
P_{n}=\lambda \times \eta \times f_{c}^{\prime} \times\left(A_{g}-A_{s t}\right)+A_{s t} \times f_{y}
$$

where

$$
\begin{aligned}
& \lambda=0.8 \text { for } f_{c}^{\prime} \leqslant 50 \mathrm{MPa} \\
& \eta=1 \text { for } f_{c}^{\prime} \leqslant 50 \mathrm{MPa}
\end{aligned}
$$

\section{4) British Standard BS 8110 [31].}

According to the British Standard BS 8110 [31], the theoretical ultimate strength or nominal strength values were computed using the following equation.

$$
P_{n}=0.67 \times f_{c u} \times\left(A_{g}-A_{s t}\right)+f_{y} \times A_{s t}
$$

where
$P_{n}=$ Ultimate strength or nominal strength of reinforced concrete columns (without taking into account the material safety factors and/or the strength reduction factors)

$A_{g}=$ gross area of concrete

$A_{s t}=$ area of reinforcing steel

$f_{y}=$ yield strength of reinforcing bars

$f_{c}^{\prime}=$ cylinder compressive strength of concrete

$f_{c u}=$ cube compressive strength of concrete

The above four well-known international standard codes were selected because such codes are generally regarded as an authoritative statement of current good practice in the field of reinforced concrete.

It is important to highlight that the in-situ residual compressive strength of concrete was evaluated for thirty-five reinforced concrete columns (un-heated and post-heated) using the ultrasonic pulse velocity method as described previously in Section 3.4. However, in this reported study, only four square (two un-heated and two post-heated up to $500{ }^{\circ} \mathrm{C}$ ) and three circular columns (two un-heated and one postheated up to $500{ }^{\circ} \mathrm{C}$ ) were tested under axial compression at ambient temperature.

Figs. 11 and 12 show the comparison of theoretical and experimental ultimate axial compressive strength values for square and circular columns. The variability in the data for the experimental results is shown in Figs. 11 and 12 by the addition of error bars. It was noted that the experimental tested values for the square and circular unheated $\left(20^{\circ} \mathrm{C}\right)$ and post-heated (uniformly heated to $500{ }^{\circ} \mathrm{C}$ ) columns agreed well with the average theoretical values calculated based on the above described well known codes equations.

It is worth mentioningthat similar to the cubes, the experimental data used in the present study for the ultimate load carrying capacity of reinforced concrete square and circular columns is also based on the uniform heating exposing to the temperatures of $500{ }^{\circ} \mathrm{C}$ (the worstcase scenario of fire). The time-temperature curves shown in Fig. 4 indicated that the temperatures within the centre of concrete columns remained relatively low compared to the furnace temperatures up to the target furnace temperature of $500{ }^{\circ} \mathrm{C}$ indicating the non-uniform heating scenario. The difference of temperatures produces the thermal gradient within the cross section of the columns.

However, after reaching the average furnace temperatures at the specified target temperature of $500{ }^{\circ} \mathrm{C}$, the furnace temperatures remainedare stayed constant until the temperatures at the centre of the reinforced concrete columns reached at the same specified target temperature of $500{ }^{\circ} \mathrm{C}$. The time required to attain the complete uniformity of temperature throughout the cross section of columns similar to the cubes represents the worst-case scenario of fire (in terms of long period of exposure to $500{ }^{\circ} \mathrm{C}$ ). 


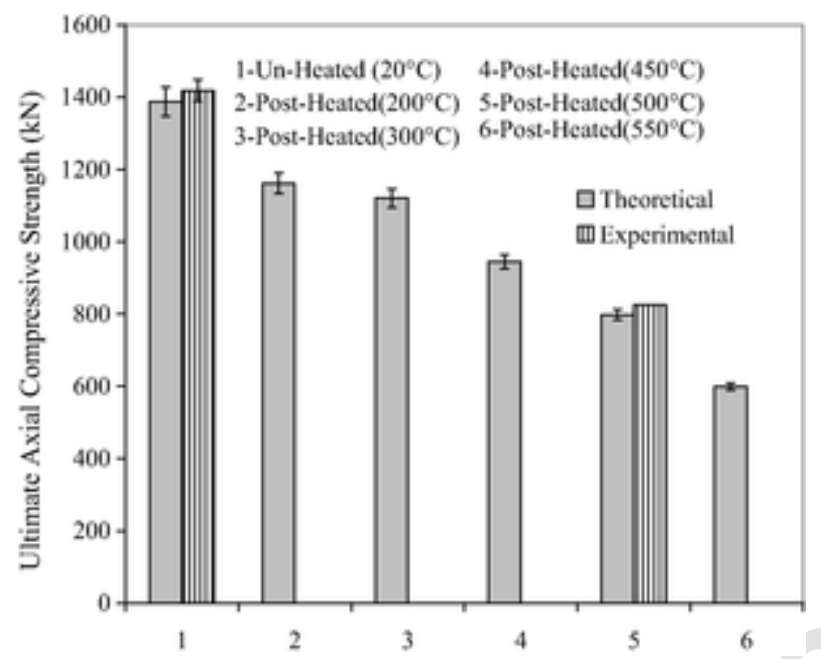

Fig. 11. Variability of data showing the theoretical and experimental ultimate axial average compressive strength of circular columns (with error bars on Y-axis).

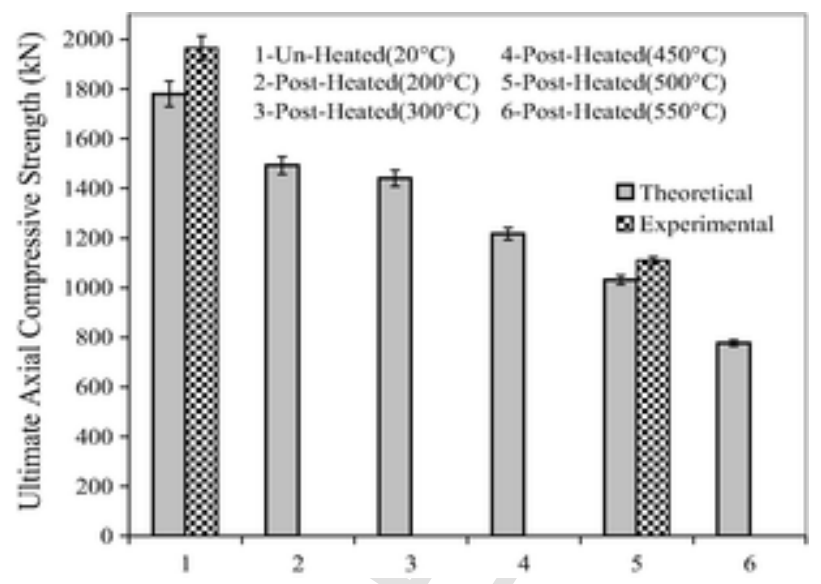

Fig. 12. Variability of data showing the theoretical and experimental ultimate axial average compressive strength of square columns (with error bars on Y-axis).

The residual ultimate load carrying capacity of fire damaged reinforced concrete columns depends mainly on the maximum fire intensity and duration of fire. Therefore, the uniform heating of reinforced concrete columns is considered the worst-case scenario compared to non-uniform heating of columns because in the uniform heating the columns are exposed to the longer duration of fire. The temperature $500{ }^{\circ} \mathrm{C}$ is considered one of the maximum peak temperature within the cross-section for fire damaged repairable concrete because at this temperature concrete retains a residual compressive strength of approximately $50 \%$ of its original strength for normal strength gravel aggregate concrete [21].

\section{Conclusion}

This paper addresses the non-destructive evaluation of residual compressive strength of concrete in existing fire damaged reinforced concrete columns. A reinforced concrete column is a critical member in the building and it can be risky to extract concrete cores for laboratory testing. The reported research work has considerable importance for the professional engineers who are involved in the field of repairing of fire damaged concrete structures.

The present study provides the conservative (safe) and simple (easy) approach for estimating the in-situ residual compressive strength of concrete in existing fire damaged reinforced concrete columns using the relationship between the ultrasonic pulse velocity and the residual compressive strength. However, the presented work is only useful to evaluate the residual compressive strength of columns over the internal temperature range $20^{\circ} \mathrm{C}-550^{\circ} \mathrm{C}$. The ultimate axial load carrying capacity of reinforced concrete columns in a real fire damaged concrete building exposed to the temperatures ranging from $20{ }^{\circ} \mathrm{C}$ to $550{ }^{\circ} \mathrm{C}$ could also be predicted using the well known code equations.

Based on the study presented, the following conclusions can be drawn.

1. The residual compressive strength of concrete decreases with increasing temperature and mostly $2-3$ month air curing results in a further, albeit slight, decrease in residual compressive strength.

2. The shape and size of the specimens had no significant effect on the pulse velocity before and after heating. However, the pulse velocity is affected due to the existence of surface cracks.

3. The residual compressive strength of the concrete on the 7 th day of cooling at ambient after exposure to $200{ }^{\circ} \mathrm{C}, 300{ }^{\circ} \mathrm{C}, 450{ }^{\circ} \mathrm{C}$, $500{ }^{\circ} \mathrm{C}$ and $550{ }^{\circ} \mathrm{C}$ was found to be $80 \%, 76 \%, 60 \%, 47 \%$ and $30 \%$ of original value respectively. 
4. The ultrasonic pulse velocity values measured in the post-heated cubes on the 7th day of cooling in ambient air after exposure to $200{ }^{\circ} \mathrm{C}, 300{ }^{\circ} \mathrm{C}, 450{ }^{\circ} \mathrm{C}, 500{ }^{\circ} \mathrm{C}$ and $550{ }^{\circ} \mathrm{C}$ were found to be $4.1 \mathrm{~km} / \mathrm{s}, 3.9 \mathrm{~km} / \mathrm{s}, 3 \mathrm{~km} / \mathrm{s}, 2.3 \mathrm{~km} / \mathrm{s}$ and $1.1 \mathrm{~km} / \mathrm{s}$, respectively.

5. The trend of the reduction in ultrasonic pulse velocity values and residual compressive strength of concrete was similar with increasing temperature.

6. The ultrasonic test is very useful for determining the uniformity in the quality of concrete and the residual strength of fire damaged concrete. However, the development of extensive cracks in post-heated concrete after exposure to temperature of $550{ }^{\circ} \mathrm{C}$ prevented the propagation of ultrasonic pulse velocity resulting in abnormal values.

7. The experimental tested values of ultimate axial compressive strength of concrete columns agree reasonably well with the theoretical values for un-heated $\left(20^{\circ} \mathrm{C}\right)$ and post-heated $\left(500{ }^{\circ} \mathrm{C}\right)$ square and circular columns. Therefore, the theoretical values of ultimate axial compressive strength of the square and circular columns could be used for the evaluation of axial compressive strength of post-heated square and circular columns over the temperature range $20{ }^{\circ} \mathrm{C}-550{ }^{\circ} \mathrm{C}$ for practical applications.

\section{Acknowledgements}

The authors acknowledge the financial support offered by Higher Education Commission (HEC), Pakistan. The authors are also

Table 6

Pulse Velocity Measurements in Un-Heated and Post-Heated Circular Columns and Associated Cubes.

\begin{tabular}{|c|c|c|c|c|c|c|}
\hline \multirow[t]{4}{*}{$\begin{array}{l}\text { Specimen } \\
\text { (Column \& } \\
\text { associated } \\
\text { cubes) }\end{array}$} & \multicolumn{3}{|c|}{$\begin{array}{l}\text { Pulse Velocity of Un-Heated } \\
\text { Specimens }[\mathrm{km} / \mathrm{s}]\end{array}$} & \multicolumn{3}{|c|}{$\begin{array}{l}\text { Pulse Velocity of Post-Heated } \\
\left(500^{\circ} \mathrm{C}\right) \text { Specimens }[\mathrm{km} / \mathrm{s}]\end{array}$} \\
\hline & \multicolumn{2}{|c|}{ Column } & $\begin{array}{l}\text { Average of } \\
\text { Cubes } \\
\text { Readings }\end{array}$ & \multicolumn{2}{|c|}{ Column } & $\begin{array}{l}\text { Average of } \\
\text { Cubes } \\
\text { Readings }\end{array}$ \\
\hline & \multicolumn{2}{|c|}{$\begin{array}{l}\text { Location of } \\
\text { Readings }\end{array}$} & \multicolumn{3}{|c|}{ Location of Readings } & \\
\hline & Top & Middle & & Top & Middle & \\
\hline $\mathrm{C} 1$ & 4.72 & 4.71 & 4.76 & - & - & - \\
\hline $\mathrm{C} 2$ & 4.66 & 4.66 & 4.61 & - & - & - \\
\hline $\mathrm{C} 3$ & 4.58 & 4.58 & 4.61 & 3.12 & 2.04 & 2.01 \\
\hline $\mathrm{C} 4$ & 4.58 & 4.58 & 4.61 & 2.44 & 1.94 & $1.92^{*}$ \\
\hline $\mathrm{C} 5$ & 4.58 & 4.58 & 4.54 & 2.41 & 1.95 & 2.85 \\
\hline C6 & 4.58 & 4.58 & 4.58 & 2.30 & 1.77 & 2.60 \\
\hline $\mathrm{C} 7$ & 4.61 & 4.61 & 4.54 & 2.33 & 1.92 & 2.74 \\
\hline $\mathrm{C} 8$ & 4.58 & 4.58 & 4.54 & 2.31 & 1.90 & 2.64 \\
\hline C9 & 4.54 & 4.54 & 4.54 & 2.41 & 1.96 & 2.40 \\
\hline $\mathrm{C} 10$ & 4.66 & 4.66 & 4.68 & - & - & - \\
\hline C11 & 4.64 & 4.64 & 4.68 & - & - & - \\
\hline $\mathrm{C} 12$ & 4.54 & 4.54 & 4.54 & 2.41 & 1.90 & 2.67 \\
\hline $\mathrm{C} 13$ & 4.54 & 4.54 & 4.54 & 2.15 & 1.75 & $1.88^{*}$ \\
\hline $\mathrm{C} 14$ & 4.65 & 4.65 & 4.76 & 2.5 & 2.22 & 2.85 \\
\hline $\mathrm{C} 15$ & 4.65 & 4.65 & 4.76 & 2.41 & 1.82 & 2.91 \\
\hline $\mathrm{C} 16$ & 4.58 & 4.58 & 4.54 & 2.43 & 1.85 & $1.88^{*}$ \\
\hline $\mathrm{C} 17$ & 4.62 & 4.62 & 4.68 & 2.31 & 2.22 & 2.27 \\
\hline $\begin{array}{l}\text { Average Pulse } \\
\text { Velocity }\end{array}$ & 4.61 & 4.60 & 4.62 & 2.42 & 1.94 & 2.43 \\
\hline $\begin{array}{l}\text { Standard } \\
\text { Deviation }\end{array}$ & \pm 0.05 & \pm 0.05 & \pm 0.08 & \pm 0.23 & \pm 0.15 & \pm 0.39 \\
\hline
\end{tabular}

grateful to the technical staff in the Structural Laboratory at the University of Manchester, UK especially John Mason whose contribution in the experimental work is really appreciated.

\section{References}

[1] H.L. Malhotra, The effect of temperature on the compressive strength of concrete, Mag. Concr. Res. 8 (23) (1956) 85-100.

[2] Design of composite steel and concrete structures. Part 1-2: General Rulesstructural Fire Design. Eurocode 4:BSEN1994-1-2:2005

[3] M.S. Abrams, Compressive strength of concrete at temperatures to $1600 \mathrm{~F}$ fire, PCA Res. Develop. Bull. (1977).

[4] Assessment and repair of fire-damaged concrete structures. Concrete Society Technical Report No. 33, 1990.

[5] L.T. Phan, Fire performance of high strength concrete, A Report of the State of the Art, National Institute of Standards and Technology, Gaithersburg, 1996.

[6] Assessment, design and repair of fire-damaged concrete structures, Technical Report-68, Concrete Society, Camberley, UK, 2008.

[7] Repairability of fire damaged structures CIB W14 Report, Fire Saf. J. 16 (4) (1990) 251-336.

[8] Fire design of concrete structures-structural behaviour and assessment, State-ofArt Report, fib Bulletin 46, 2008.

[9] Fire resistance of concrete structures, In: Report of a Joint Committee of the Institution of Structural Engineers and the Concrete Society, 1975.

[10] Design of concrete structures. Part 1-2: General Rules-structural Fire Design Erocode 2: BS EN 1992-1-2: 2004

[11] U. Wickstrom, A very simple method for estimating temperature in fire exposed concrete structures, In: Fire Technology Technical Report, SP-RAPP 1986, 46, National Testing Institute, Swedish, 1986.

[12] J.H. Bungey, S.G. Millard, Testing of Concrete in Structures, third ed., 1996.

[13] T.T. Lie, T.J. Rowe, T.D. Lin, Residual strength of fire-exposed reinforced concrete column, ACI Struct. J. 92 (SP92-09) (1986) 153-174

[14] Testing concrete in structure, Part-1: Cored specimens, taking examining and testing in compression, Part-2:Non-destructive testing, determination of rebound number, Part-3: Compressive strength of test specimens, Part-4 determination of ultrasonic pulse velocity. British Standard Institution, BSEN12504-4:2004

[15] S.V. Oberoi, A. Goenka, Assessment of strength with inputs from ultrasonic pulse velocity measurement, In: Recent Trends in Civil Engineering Organized by Civil Engineering Society, IT-BHU, Varanasi, 2004pp. 89-96.

[16] D.G. Watkeys, Non-destructive testing of concrete subject to fire attack (M.Sc. (Eng.) Thesis), University of London, UK, 1955.

[17] F.G. Thomas, C.T. Webster, The fire resistance of reinforced concrete columns. Investigations on building fires, National Building Studies Research Paper No. 18, Part VI, 1953.

[18] L.T. Phan, Fire performance of high strength concrete, In: A Report of the State of the Art. Maryland 20899, NISTIR 5934, Building and Fire Research Laboratory, National Institute of Standards and Technology, Gaithersburg, 1996.

[19] A.J. Purkiss, Fire Safety Engineering Design of Structures, second ed., 2007.

[20] K.D. Hertz, Concrete strength for fire safety design, Mag. Concr. Res. 57 (8) (2005) 445-453.

[21] E.W. Marchant, A Complete Guide to Fire and Buildings, Medical and Technical Publishing, London, 1972.

[22] O. Arioz, Retained properties of concrete exposed to high temperatures: size effect, Fire Mater. 33 (5) (2009) 211-222.

[23] P.H. Perkins, Repair Protection and Waterproofing of Concrete Structures, third ed., 1997.

[24] C.S. Poon, S. Azhar, M. Anson, Y.L. Wong, Strength and durability recovery of fire-damaged concrete after post-fire-curing, Cement Concr. Res. 31 (2001) 1307-1318.

[25] E. Annerel, Assessment of the residual strength of concrete structures after fire exposure (PhD thesis), Ghent University, 2010.

[26] C. Castillo, A.J. Durrani, Effect of transient high temperature on high strength concrete, ACI Mater. J. 87 (1) (1990) 47-53.

[27] H. Yang, Y. Lin, C. Hsiao, J.Y. Liu, Fire Safe. J. 44 (1) (2009) 121-130.

[28] Building Code Requirements for Structural Concrete ACI 318-11 and Commentary Reported by ACI Committee 318, 2011.

[29] Design of Concrete Structures, Canadian Standard Association CSA A23.3.04, 2004.

[30] Design of concrete structures. Part-1-1: General rules and rules for buildings, Eurocode 2: BS EN 1992-1-1:2004.

[31] Structural use of concrete.Part-1: Code of practice for design and construction, BS 8110-1:1997. 